\title{
Hodnocení inkluzivních jednotek žáků se specifickými vzdělávacími potřebami do hodin běžné tělesné výchovy
}

\section{Evaluation of Inclusion of Pupils with Special Education Needs to Common Physical Education Lessons}

\author{
Jana Sklenaříková', Radka Bartoňová', Alena Skotáková2, Lýdie Brázdová2 \\ Fakulta tělesné kultury, Univerzita Palackého, Olomouc ${ }^{1}$ \\ Fakulta sportovních studií, Masarykova univerzita, Brno²
}

\begin{abstract}
Abstrakt
Inkluzi popisujeme jako vyvrcholení integračního procesu, kdy jsou vytvořeny podmínky tak, aby bylo možné začleněnit jedince se speciálními vzdělávacími potřebami do intaktní populace. Cílem výzkumu bylo specifikovat fungování inkluze u dètí se zdravotním postižením do hodin tělesné výchovy $\checkmark$ České republice na vybraných základních školách. Na základě škály DIC-CIT (Válková, Bartoňová \& Ahmetašević, 2012) byl proveden výzkum, který nastínil činnosti žáků se zdravotním postižením $\checkmark$ inkluzivní vyučovací jednotce. Výsledky škálování pomocí DIC-CIT odhalily časové charakteristiky skutečného začlenění žáků do hodin tělesné výchovy, do činností pedagogů a asistentů pedagoga. Z výsledků je zřejmé, že na vybraných základních školách se inkluze v tělesné výchově dostává na vysokou úroveň.
\end{abstract}

\begin{abstract}
Inclusion is described as the culmination of the integration process when conditions are created so that it can integrate individuals with special educational needs in intact population. The aim of the research was to determine how works inclusion of children with health disabilities in physical education classes in the Czech Republic at the various schools. It was performed research based on the range of DIC-CIT (Válková, Bartoňová \& Ahmetaševič, 2012) which outlined the activities of students with disabilities in inclusive class. Results scaling by using CIT-DIC revealed time characteristics of the actual integration of students into physical education, into parallel activities and teacher's assistants activities. From the results of our research is clear that in selected schools with inclusion in physical education receives at a high level.
\end{abstract}

Klíčová slova:

inkluze, tělesná výchova, zdravotní postižení, pedagogicky využitý čas, škála CIT

Keywords:

integration, inclusion, physical education, disability, pedagogical use of time, scale of CIT

Tento přispěvek vznikl v rámci projektu: „Podpora vytváreni excelentnich týmů a intersektorální mobility na Univerzitě Palackého v Olomouci II. ", reg. č. CZ.1.07/2.3.00/30.0041 


\section{ÚVOD}

Integrace osob se zdravotním postižením je $\mathrm{v}$ této době velkým fenoménem. V současné době se integrace rozběhla plným proudem a mnohde už není jako integrace vnímána. Panují různé názory na integraci dětí se zdravotním postižením. Dle Kudláčka (2008) se slovo integrace stalo módním trendem a je využíváno i zneužíváno učiteli, zástupci škol i rodiči žáků s postižením a jejich nepostižených spolužáků.

V České republice se problém integrace do běžných škol začal řešit v roce 1991 (Michalík, 2000, Müller, 2001). V současné době integrovaných dětí se zdravotním postižením v běžných školách pozvolna přibývá (Kudláček \& Ješina, 2014). V České republice byla většina dětí se zdravotním postižením do roku 1991 segregována ve speciálních školách. Od roku 1991 do roku 2004 se integrace realizovala podle metodických předpisů ministerstva školství. V roce 2004 byla integrace podpořena novým školským zákonem, který byl v roce 2005 doplněn Vyhláškou o vzdělávání dětí a žáku se speciálními vzdělávacími potřebami a dětí a žáků mimořádně nadaných (Kudláček, 2008). Legislativní změny dopomohly $\mathrm{k}$ začlenění žáků do běžných škol. Integrace není jen o začlenění jedince do většinové společnosti. Je to také o vnímání jinakosti, postojích a lidské přirozenosti (Válková, 2012). Termín integrace v tělesné výchově (ITV) znamená zařazení různých typů jedinců do společných forem tělesné výchovy (TV). Tato forma integrace je založena na filozofii, že žáci by měli být vzděláváni a vychováváni společně v jedné tř́idě. Učitel tak obecně musí učinit nezbytná opatření v pedagogice, didaktice a osnovách, aby všichni žáci mohli dosáhnout cílů TV (Kudláček, 2008). V České republice, v souvislosti s ITV dochází k participaci jednoho či více žákủ se speciálními vzdělávacími potřebami (SVP) společně s intaktními spolužáky (Ješina, Bartoňová, Gebauer, Rybová, Kučera, \& Vyhlídal, 2011). Zatímco literatura na téma speciální pegagogiky poskytuje bohatou řadu studií o začleňování žáků s speciálními vzdělávacími potřebami (SVP) (Cushing \& Kennedy, 1997; Cushing, Clark, Carter \& Kennedy, 2005; Jackson, Ryndak \& Wehmeyer, 2008/2009), povahy vzdělávání v tělocvičně nebo na sportovišti se podstatně liší od nastavení vzdělávání v učebně (Lieberman, Houston-Wilson, \& Kozub, 2002). Tito studenti mají obvykle slabší kognitivní, sociální, pohybový vývoj, nebo adaptivní chování (Hunt, Alwell, Farron - Davis \& Goetz, 1996).

\section{Inkluze}

Termín sociální inkluze je mladý a poprvé byl použit ve Francouzské vládě v roce 1974. Spolu se sociálním vyloučením, začal termín postupně převládat $\mathrm{v}$ politických agendách mnoho západních vlád, a speciálně těch v Evropě (Smith, 2009). Začleňování jedinců s postižením je prostředkem $\mathrm{k}$ dosažení cílů socializačních a cílů celospolečenské důležitosti a to proto má tento směr především celospolečenský a celoživotní kontext pro osoby z minoritní i majoritní společnosti (Válková, 2008).

Sherrill (1998, 241) o inkluzi píše: „Inkluze má mnoho významů, ale typicky je spojená s kvalitou života v co nejméně omezujícím prostředi a je sociálni odpovědností. “ Dále uvedla, že profesionálové musí být připravování na inkluzi. Musí znát druhy doplňkové pomoci a podpory přístupné za účelem maximalizovat možnosti, aby studenti se zdravotním postižením měli užitek $z$ výuky běžné tělesné výchovy.

Co nejméně omezující prostředí pro studenty se zdravotním postižením je stejné, jako prostředí pro studenty bez postižení (Block, 2000). Jinými slovy inkluze naznačuje, že všechny děti mají stejnou př́iležitost zapojit se do vzdělávání a aktivit na odpovídajícím stupni a s odpovídající podporou (McMurray, 2003).

Dinold \& Válková $(2003,52)$ definují inkluzi jako: ,proces utvářený způsobem každodenní životní integrace, vzděláváním a hodinami tělesné výchovy. Inkluze není cill, ale zpưsob socializace, nezávislého života a je charakterizovaná r̆adou variant od té nejvice omezujici po co nejméně omezujicí prostredi. “"

Kasser \& Lytle $(2005,6)$ popisují inkluzivní pohybové aktivity a jejich benefity: „Inkluzivní pohybové aktivity zajištují, že všichni jedinci, navzdory schopnostem nebo věku, maji stejné príležitosti v pohybových aktivitách. Tyto př́ležitosti by měly zahrnovat možnost a rozhodování, tvořit 
smysluplné zapojení a úspěch, který posiluje všechny účastníky. Jinými slovy, inkluzivní pohybová aktivita je definována jako prístupné pohybové aktivity poskytovány všem jedincům napřič životem $v$ rüzných prostředich".

Cílem výzkumu bylo specifikovat fungování inkluze u dětí se zdravotním postižením do hodin tělesné výchovy v České republice na vybraných základních školách.

\section{METODIKA}

\section{Výzkumný soubor}

Předmětem výzkumu byli žáci se speciálními vzdělávacími potřebami (SVP) (žáci s různými druhy tělesného postižení), na vybraných na základních školách v České republice, kteří se účastnili tělesné výchovy v hlavním proudu vzdělávání (Tab.1). Sběr dat probíhal ve čtyřech tř́íách prvního, respektive druhého stupně, $v$ jednotkách tělesné výchovy na základních školách, které umožňují inkluzi žáků se SVP a spolupracují se speciálně pedagogickým centrem. Do výzkumu byli zařazeni tři žáci a jedna žákyně, věk 10,25 $\pm 3,25$. Tři žáci využívali služeb asistenta pedagoga a jeden nevyužíval.

Tab.1 Přehled probandů a jejich diagnózy

\begin{tabular}{|c|c|c|c|l|c|c|l|c|}
\hline Proband & P & Třída & Věk & Diagnóza & $\mathbf{f Z / I}$ & PU & Obsah TV & A \\
\hline A & CH & 7 & 13 & $\begin{array}{l}\text { Aspergerův } \\
\text { syndrom }\end{array}$ & $12 / 1$ & M & $\begin{array}{l}\text { Skok do výšky, průpravná } \\
\text { cvičení k volejbalu }\end{array}$ & NE \\
\hline B & CH & 8 & 14 & $\begin{array}{l}\text { DMO - diparéza, } \\
\text { spastická forma }\end{array}$ & $11 / 1$ & M & Nácvik házené a fotbalu & ANO \\
\hline C & CH & 1 & 7 & $\begin{array}{l}\text { Lehké mentální } \\
\text { postižení }\end{array}$ & $24 / 1$ & Ž & Sportovní a míčové hry & ANO \\
\hline D & D & 1 & 7 & $\begin{array}{l}\text { DMO - diparéza, } \\
\text { spastická forma }\end{array}$ & $25 / 1$ & Ž & Míčové hry - florbal & ANO \\
\hline
\end{tabular}

Poznámka: $P$ - pohlaví; $f Z / I$ - počet žáků ve třídě zdravých/integrovaných; $P U$ - pohlaví učitele; $A$ - asistent pedagoga, DMO - dětská mozková obrna

\section{Použité metody}

Při sběru dat byly použity instrumenty DIC-CIT podle Válkové a kol. (2012). Didactic Inclusive Categories - Critical Incident Techniques neboli Didakatické Inkluzivní Kategorie - Technika Kritických Př́ípadů (DIC-CIT) zahrnuje zjištění, do jaké míry je žák se speciálními vzdělávacími potřebami zapojen do hodin tělesné výchovy. Tato metoda je základní technikou pro hodnocení činnosti žáků v inkluzivní vyučovací jednotce školní tělesné výchovy. Tvůrcem CIT, je John C. Flanagan (1954), se nechal inspirovat od Francise Galtona, který se zabýval životem psychiatrických (problémových) pacientů. Proto se používá termín „kritický případ“. Flanagův termín „kritický př́ípad“ v tomto kontextu nahrazujeme termínem „didaktická inkluzivní kategorie“ (DIC). Zkratky pro zápis posuzovatele vycházejí z angličtiny, (resp. z latinského základu) a jsou shodné i pro užití v češtině (Válková a kol. 2012).

Behěm pozorování $\mathrm{v}$ hodinách TV byly zaznamenávány kategorie související s časovými jednotkami (sekundy, minuty). Tyto zásady byly použity v pedagogice sportu (Flanders, 1967; Pieron \& Cheffers, 1973). V českém prostředí byl pozorovací protokol využit v rámci analýzy pohybové aktivity v konstrukci ADI (Analýzy Didaktické Interakce) (Dobrý \& Svatoň, 1978). Princip CIT byl použit pro posouzení procesu u sportovních her, zejména basketbalových zápasů (Válková, 1974) a hodnocení efektu hry u basketbalistů (Válková, 1990). Záměr oveřit nástroj týkající se inkluzivních vyučovacích jednotek byl stanoven na konci 90. let na olomoucké univerzitě (Kudláček, 1997; Obrusníková, 1998). Pozorovatelé museli projít minimálním školením, aby mohl být př́stroj využit při hodnocení inkluzivního procesu a výsledky bylo možno považovat za platné. Kroky př́pravy 
zahrnovali výcvik: znalost přesného obsahu didaktických kategorií, pamětová školení kategorií, odborné př́pravy $\mathrm{v}$ rámci poradenství, reálný trénink se suprevizorem a zpětnou vazbu (Ahmetašević, A., Bartonová, R., \& Válková, H., 2012).

Adminitrace pozorování: pozorování a proces hodnocení byl realizován po dohodě s vyučujícím. Cíl a obsah TV byl oznámen všem studentům třídy i pozorovateli. Pozorovatel (zapisovatel), se nacházel př́mo $v$ tělocvičně na bezpečném místě pro něj a studenty třídy. Bylo nutné si stanovit začátek vyučovací jednotky a po celou dobu pozorování sledovat čas. Pozorovatel zaznamenal do zápisového archu skutečné didaktické kategorie vztahující k danému času. Další poznámky si pozorovatel také do protokolu sepsoval.

Popis kódování podle manuálu Válková a kol. (2012):

I-Inkluzivní (integrativní, společná)

ICE: Inkluzivní (v kognitivně emotivní činnosti); I - M: Inkluzivní (pohybová) bez modifikací; I+M: Inkluzivní (pohybová) s modifikací; I - MA: Inkluzivní (pohybová) s asistentem, ale bez modifikací; I + MA: Inkluzivní (pohybová) s asistentem a s modifikací; ISU: Inkluzivní podpůrná (suportivní)

$P$ - Paralelní (žáci jsou fyziky i topicky společně, cvičení pro žáka se SVP má jiný cíl a jiný úkol i obsah)

PCO: Doplňková cvičení (jako ostatní, v kooperaci); PEx: Doplňková cvičení (extra určená, zorganizovaná.

$S$ - Separované (žák společně se třídou necvičí, není aktivní, ale fyzicky je prrítomen)

SNO: Separovaná, není aktivní (nejde to, NO); STO: Separovaná, není aktivní (time-out, TO); Sex: Separovaná, není aktivní (exkluze - ex, žák ápriori není začleněn)

\section{Metody sběru a zpracování dat}

$\mathrm{Na} 4$ různých základních školách jsme získali data zápisem do archu při osobní návštěvě. $Z$ důvodu složitého procesu násvětěvy inkluzivních jednotek TV a získání konsensu byly odpozorované 4 vzučovací jednotky TV.

Během zpracování dat jsme porovnali časovou škálu začlenění žáků s různými typy zdravotního postižení podle kategorií CIT škály. Výsledky jsme zpracovali v programu MS Excel a posoudili, kolik pedagogického času žáci se zdravotním postižením stráví aktivně a kolik pasivně. Posuzovací škálu DIC-CIT lze považovat za ověřenou pro hodnocení míry (procent času) začlenění žáka se zdravotním postižením do vyučovací jednotky tělesné výchovy, a to za podmínek proškolení posuzovatelů a dodržení obsahu DIC-CIT.

Pro statistickou verifikaci je zapotřebí odpozorovat v praxi větší počet vyučovacích jednotek (cca 5 na jednotlivých stupních škol s diferencovanou diagnózou začleněného žáka se zdravotním postižením). $\mathrm{Z}$ toho důvodu jsme se přiklonili k metodě kazuistik.

\section{VÝSLEDKY}

V tab. 2 je sumář všech odpozorovaných vyučovacích jednotek běžné tělesné výchovy na základních školách. 
Tab. 2: Sumář inkluzivních vyučovacích jednotek tělesné výchovy

\begin{tabular}{|l|c|c|c|c|c|c|c|c|c|}
\hline & & ICE & I-M & I+M & I-MA & I+MA & & Sum. & ZH/KH \\
\hline \multirow{2}{*}{ Proband A } & Čas (sec.) & 575 & 1292 & & 135 & 345 & & 2347 & $10: 10 / 10: 45$ \\
\cline { 2 - 11 } & Procenta (\%) & 24.5 & 55 & & 5.8 & 14.7 & & & \\
\hline \multirow{2}{*}{ Proband B } & Čas (sec.) & 440 & 1665 & 40 & & & & 2145 & $11: 00 / 11: 35$ \\
\hline & Procenta (\%) & 20.5 & 77.8 & 1.9 & & & & & \\
\hline \multirow{2}{*}{ Proband C } & & & & & & & STO & & \\
\hline & Čas (sec.) & 260 & 500 & 45 & 150 & & 275 & 1185 & $11: 20 / 11: 45$ \\
\cline { 2 - 11 } & Procenta (\%) & 21.9 & 42.2 & 3.7 & 12.7 & & 23.2 & & \\
\hline \multirow{2}{*}{ Proband D } & & & & & & & PEx & & \\
\cline { 2 - 10 } & Cras (sec.) & 645 & 1000 & & 70 & & 300 & 2015 & $10: 10 / 10: 45$ \\
\cline { 2 - 9 } & Procenta (\%) & 32 & 49.6 & & 3.5 & & 14.9 & & \\
\hline
\end{tabular}

Poznámka: ICE: kognitivně-emotivní; I-M: pohybová bez modifikací; I+M: pohybová s modifikací; I-MA: pohybová s asistentem, bez modifikací; I+MA: pohybová s asistentem a s modifikací; STO: Time-out (potřebuje oddech); PEx: Doplňková cvičení - extra; Sum.: součet ZH/KH - Reálný čas: zahájení hodiny/ konec hodiny

\section{Proband A}

Jednotlivé části hodiny tělesné výchovy byly dobře rozvržené (Tab. 2). Nejdelší část hodiny tvořila I-M Inkluzivní (pohybová) bez modifikací, kdy žáci cvičí společně a mají stejný obsah i úkol hodiny. Tato část v měření tvořila $55 \%$ z celkového času hodiny tělesné výchovy, což odpovídá asi 22 minutám. Dalš́ část hodiny tvořila jednotka ICE - Inkluzivní, která trvala $24,7 \%$, což v měření odpovídá 10 minutám z celkové hodiny tělesné výchovy. Tato část zabrala opravdu málo času, přitom každému žákovi byla věnována dostatečná pozornost. 5,7 \% tvořila jednotka I-MA Inkluzivní (pohybová) s asistentem, ale bez modifikací, což odpovídá pouze 2,5 minuty z celkového času hodiny TV. Tato část byla ze všech nejkratší, chlapec byl samostatný a výpomoc od asistenta v hodině TV prŕiliš nepotřeboval. 14,7 \% trvala část I + MA Inkluzivní (pohybová) s asistentem a s modifikací, která tvořila asi 6 minut z celkové hodiny TV. I tato část trvala velmi krátkou dobu vzhledem k podmínkám, že se žák se SEP společně s ostatními žáky učili nové technice skoku do výšky i volejbalového odrážení.

\section{Proband B}

V měření zabírala nejdelší část I-M Inkluzivní (pohybová) bez modifikací. Tato část tvořila 77,8\%, což odpovídá skoro 28 minutám z celkového trvání hodiny necelých 36 minut a trvala téměř celou hodinu, protože žáci a žákyně prováděli pohybové aktivity, které znali a vyučující nemusel ztrácet čas vysvětlováním nových cviků. I-CE Inkluzivní (v kognitivně emotivní činnosti) trvala přibližně 7 minut, což odpovídá $20,7 \%$ z celkového času tělesné výchovy. Trvání této části bylo přiměřené a odpovídalo podmínkám. Jednotka I+M Inkluzivní (pohybová) s modifikací tvořila pouze 1,9\% z celkového času hodiny TV, což je nepatrná část a odpovídá pouze 40 sekundám. Takovým způsobem probíhají i hodiny tělesné výchovy, kde nejsou žádní žáci se specifickými potřebami. Žák se SEP byl do hodiny tělesné výchovy plně začleněný a s vykonáváním obsahu tělesné výchovy neměl problém.

\section{Proband C}

Hodina tělesné výchovy pro žáka s lehkým mentální postižením trvala pouze 20 minut. Nejdelší část hodiny TV tvořila jednotka I-M Inkluzivní (pohybová) bez modifikací (Tab. 2), která tvořila 42,2\%, což odpovídá přibližně 8 minutám. Vzhledem k celkovému trvání hodiny pro žáka se SVP je 8 minut přiměřených, ale oproti ostatním měřením, chlapec cvičil asi o třetinu hodiny méně. Proband měl cvičit na doporučení lékaře pouze jednu vyučovací hodinu ze dvou. Další část hodiny tvořila jednotka 
ICE inkluzivní (v kognitivně emotivní činnosti), která trvala 21,9 \% z celkového času hodiny TV, což odpovídá přibližně 4 minutám. 3,7\% tvořila část I+M Inkluzivní (pohybová) s modifikací, která trvala pouhých 45 sekund.

Cviky, které žáci prováděli, byly jednoduché, proto vyučující zvolila pouze jednu modifikaci cviku při startech. Další část hodiny tvořila jednotka I-MA Inkluzivní (pohybová) s asistentem, ale bez modifikací, která trvala 2,5 minuty, což je 12,7 \% z celkového času TV. Vzhledem k věku a postižení žáka tato část netrvala dlouho. Poměrně déle trvala část STO Separovaná (time out, TO), kdy žák nebyl aktivní a necvičil z důvodu hluku v tělocvičně. Tato část tvořila $23,2 \%$ z celkového času hodiny TV, což je asi 4,5 minuty. Když započítáme do celkového trvání hodiny i tuto část, pro žáka se SVP trvala hodina TV pouze 15 minut. $V$ tomto měření bylo použito nejvíce inkluzivních jednotek, což je adekvátní k věku žáka se SEP, protože byl ze všech žáků z měření nejmladší i vzhledem k jeho postižení.

\section{Proband D}

Vyučovací hodina TV trvala přibližně 33,5 minuty. Nejdelší část tvořila jednotka I-M Inkluzivní (pohybová) bez modifikací (Tab. 2), která trvala skoro 17 minut, což odpovídá 49,6 \% z celkové hodiny TV. Další nejdelší část hodiny tvořila jednotka ICE Inkluzivní (v kognitivně emotivní činnosti), která trvala asi 11 minut, což odpovídá $32 \%$ z celkového času tělesné výchovy. Jednotka I-MA Inkluzivní (pohybová) s asistentem, bez modifikací trvala pouze 70 sekund, což odpovídá 3,5 \% z celkového času tělesné výchovy. Vzhledem k pohybovému omezení žákyně, tato část trvala nepatrnou část hodiny. Pro žákyni se SEP byla vhodně zvolená pozice brankáře, kde se mohla pohybovat samostatně, nepotřebovala asistenci a nehrozilo jí nebezpečí úrazu. Poslední jednotkou, která tvořila část hodiny TV, je PEx Doplňková cvičení (extra určená, zorganizovaná). Tato část hodiny trvala 5 minut, což odpovídá $14,9 \%$ z celkového času hodiny TV.

\section{DISKUZE}

Výzkum si kladl za cíl přiblížit problematiku využitelnosti pedagogického času v hodinách inkluzivní tělesné výchovy. Termín inkluze není v Českém prostředí legislativně ani odborně příliš ukotven, ale je často používaný v zahraniční literatuře. Stejně jako Ješina, Kudláček a kol. (2011) můžeme vnímat inkluzi jako vyvrcholení integračního procesu, kdy jsou vytvořeny podmínky tak, aby bylo možné začlenění jedince se SVP a jeho účast na jednotlivých činnostech. Dle Kudláčka $(2008,16)$ je nutné si uvědomit, že tzv. úplná integrace není vždy optimálním řešením. Při začleňování žáků s e zdravotním postižením bychom měli vycházet z filosofie tzv. nejméně omezujícího prostředí, které žáka minimálně limituje v naplnění jeho životního potenciálu. Snaha podporovat úspěšnou integraci začíná cíleně s rozvojem pozitivních postojů okolí, které musí být prvotně odhaleny a postupně realizovány (McMurray, 2003).

Výzkum Spurné, Rybové a Kudláčka (2010) zabývající se analýzou podmínek integrované tělesné výchovy v České republice zjistil, že z počtu 111 žáků s tělesným postižením bylo uvolněno na základě doporučení lékaře 51 žáků. Ze získaných výsledků vyplývalo, že míra začlenění žáků se odvijí od formy a stupně postižení.

Winnick (2000) tvrdí, že tělesná výchova by měla vyhovět potřebám všech studentů, připravit je na aktivní život, a umožnit jim zapojit se do pohybových aktivit během jejich života. Tělesná výchova může být velmi silným faktorem ovlivňujícím úspěch či selhání inkluze. Proč jsou tedy děti se zdravotním postižením často s tělesné výchovy osvobozování? Jedna z verzí je, že učitelé nemají dostatek zkušeností s touto problematikou. Největší překážky v začlenění studentů se zdravotním postižením se vztahují k pedagogické připravenosti a postojům pedagogů stejně jako vnímané a aktuální bariéry ve výuce, které mohou zahrnovat vybavení, programování a čas (Sherrill, 1998, 241). Názory, chování, znalosti a zkušenosti s překonáváním překážek integrace jsou úzce propojeny. Podle některých specialistů je jedním z řešení kvalitní příprava budoucích učitelů na integraci dětí se zdravotním 
postižením (Bartoňová \& Vítková, 2007). Důkazy v mnoha př́ípadech podporují fakt, že tělesná výchova a pohybové aktivity jsou velice důležité zejména pro děti se zdravotním postižením (Block, 2000; Coppenolle, De Potter, Van Peteghem, Djobova \& Wijns, 2003; Sherrill, 2004; Jowsey, 1992).

Mnoho základních škol v České republice umožňuje inkluzi žáků se speciálními vzdělávacími potřebami a zároveň spolupracují se speciálně pedagogickým centrem. Na základních školách se nejčastěji vyskytovali žáci s poruchami učení jako dyslexie, dysgrafie, dyskalkulie nebo s vadami řeči. Na tyto žáky jsme ve svém výzkumu nezaměřovali, jelikož nemají problémy s náplní tělesné výchovy. Další skupinou žáků se speciálními potřebami jsou děti s poruchou autistického spektra a děti s poruchou pozornosti. Ti s náplní tělesné výchovy neměli téměř žádný problém a jsou dostatečně zapojeni i s ostatními spolužáky do hodiny tělesné výchovy. Podobným př́padem byl i chlapec s Aspergerovým syndromem. U žáka nebyl v hodině tělesné výchovy př́itomný asistent. Žák byl do hodiny tělesné výchovy zapojen nejlépe $\mathrm{z}$ celého zkoumaného souboru. Během hodiny byla zvolena pouze nepatrná modifikace cviku při skoku do výšky, kdy chlapec skákal při větší výšce přes gumu místo tyče. Takové modifikace bývají používané i u žáků, kteří nepotřebují speciální př́istup, jen mají problém se zvládnutím cviku. Žák potřeboval více pozornosti a vysvětlení, než ostatní žáci, jinak byl velmi samostatný. Z měření můžeme usoudit, že žáci s tímto postižením nemají problém s náplní tělesné výchovy, nevyžadují téměř speciální př́ístup a hodina nemusí být upravována jejich možnostem.

Nejméně se podařilo z provedených měření začlenit do hodiny tělesné výchovy žáka s lehkým mentálním postižením, který chodil do 1 . třídy. Žáka bylo těžké zapojit do hodiny tělesné výchovy kvůli jeho postižení i částečně kvůli věku, protože byl oproti probandům z ostatních měření nejmladší. Žák měl také i menší zájem se zapojit do pohybových aktivit s ostatními spolužáky.

Žákyně s dětskou mozkovou obrnou chodila do 1. tř́ídy a její začlenění do hodin tělesné výchovy bylo nejnáročnější ze všech měření, protože byla pohybově limitována. Přesto se zapojení do TV podařilo, mohla vykonávat pouze malou řadu sportovních aktivit a ostatní žáci nebyli v hodině tělesné výchovy nijak omezováni.

Žáci byly dostatečně zapojováni do tělesné výchovy, protože dva z nich nepotřebovali během tělesné výchovy vůbec speciální prrístup a náplň hodiny zvládali bez problémů. Žákyně s DMO sice vyžadovala specifičtější prístup, ale v hodině TV byla také dostatečně zapojená. Bez metodické podpory a úpravy podmínek v TV by účast žáka se SVP byla složitá. Každý žák se SVP má určitá specifika. Integrace v TV je bez dostatečné podpory většinou pro učitele TV př́liš náročná (Ješina, Kudláček et al., 2011). Kudláček (2008) tvrdí, že pokud se nepodaří uzpůsobit podmínky ve školní TV, mohou integrací trpět jak žáci se SVP, tak i jejich spolužáci a učitel TV. Lienert, Sherrill a Myers (2001) uvádějí, že ve většině př́ipadů rozhodnutí o začlenění žáka se SVP není v kompetenci učitele TV. Učitelé však rozhodují o tom, $\mathrm{v}$ jaké míře bude tento žák $\mathrm{v}$ jejich hodinách zapojen do pohybových aktivit. Morley, Bailey, Tan \& Cooke (2005) se zaměřili na zjištění názorů učitelů TV týkajících se integrace. Jejich závěry poukazují na bariérovost prostředí a nedostatek podpory pro integraci. Fejgin, Talmor \& Erlich (2005) zjistili u učitelů TV v Izraeli, že překážky v integraci jsou prostorové podmínky, problémy s evaluací žáků, bezpečnost, modifikace vlastní výuky a komunikace s rodiči žáků se SVP.

Někteří autoři (Ješina \& Kudláček a kol., 2011; Bartoňová 2007) poukazují na bariéry při realizaci TV v České republice. Při integraci se žák se SVP musí přizpůsobit nejenom požadavkům vyučování, autoritě učitele, ale i skupině zdravých, lépe disponovaných vrstevníků. V této konfrontaci se dost často zdůrazňuje jeho role odlišného. Stává se to na úrovni vztahu ke skupině spolužáků, od nichž se vždycky více či méně liší. $V$ běžné škole získává takové dítě mnohdy první větší zkušenosti s postoji široké veřejnosti $\mathrm{k}$ lidem se zdravotním postižením, především prostřednictvím spolužáků, jejich rodičů a učitelů (Vágnerová, 2003).

Vybrané základní školy v Brně umožňují vzdělávání žáků se speciálními potřebami. O faktu, že umožňují jejich vzdělávaní a ve spolupráci se speciálním pedagogickým centrem sestavují svým žákům individuální vzdělávací plány, informují veřejnost na svých internetových stránkách. 


\section{ZÁVĚRY}

Inkluze žáků se speciálními potřebami má smysl, protože je neúčelné, kdyby žáci museli chodit kvưli svému postižení do speciálních škol, jestliže zvládají i učivo na běžné základní škole. České školství je inkluzivnímu vzdělávání nakloněné a inkluze v naší republice se dostává na vysokou úroveň. Určitě se dá nalézat nové metody a postupy při výuce a řešení, jak nejlépe zapojit žáky se SVP do vyučovacích hodin, aby hodina měla co největší přínos pro všechny zúčastněné. Je však nezbytné respektovat určité věci, které sebou inkluze přináší. Za prvé není vhodná pro každého žáka, a za druhé pokud se nepodaří uzpůsobit podmínky ve školní TV, mohou inkluzí trpět jak žáci se zdravotním postižením, tak i jejich spolužáci a učitel TV.

\section{Literatura}

Ahmetašević, A., Bartonová, R., \& Válková, H. (2012). Physical Education Inclusion Assessment - Critical Incident Technique. Sport Science, 5(1), 49-52.

Bartoňová, M. (2007). Specifické poruchy učení: text k distančnímu vzdělávání. Brno: Paido, 237.

Bartoňová, M., \& Vítková, M. (2007). Strategie ve vzdělávání dětí a žáků se speciálními vzdělávacími potřebami. Texty k distančnímu vzdělávání. Brno: Paido.

Block, M. (2000). A teacher's guide to inclusing students with disabilities in general physical education. Baltimore, MD: Paul H. Brookes.

Coppenolle, H.V., De Potter J-C., Van Peteghem A., Djobova S., \& Wijns K. (2003). Inclusion and integration through adapted physical activity, pp. 47-73.

Cushing, L. S., \& Kennedy, C. H. (1997). Academic effects of providing peer support in general education classrooms on students without disabilities. Journal of Applied Behavior Analysis, 30(1), 139-151.

Cushing, L. S., Clark, N. M., Carter, E. W., \& Kennedy, C. H. (2005). Access to the General Education Curriculum for Students With Significant Cognitive Disabilities. Teaching Exceptional Children, 38(2), 6-13.

Dinold, M. \& Válková, H. (2003). Inclusion in physical education in schools. In Van Coppenolle, H., De Potter, J. C., Van Peteghem, A., Djobova S. \& Wijns, K.(Eds.), Inclusion and integration through Adapted Physical Activity. Leuven: THENAPA

Dobrý, L., \& Svatoň, V. (1978). Analysis of teachers instructional activities in physical education. In Svoboda and Dobrý (Eds.). Didactic studies in physical education, (pp. 63-106). Praha: Univerzita Karlova.

Fejgin, N., Talmor, R., \& Erlich, I. (2005). Inclusion and burnout in physical education. European Physical Education Review, $11(1), 29-50$.

Flanagan, J.C. (1954). The critical incident technique. Psychol. Bull.,51(4), 327-358.

Flanders, N. (1967). Interaction analyses, theory, research and application. Massachusetts: Addison - Wesley.

Hunt, E., Alwell, M., Farron -Davis, F., \& Goetz, L. (1996). Creating socially supportive environments for fully included students who experience multiple disabilities. Journal of the Association for Persons with Severe Handicaps, 21(2), 53-71.

Jackson, L. B., Ryndak, D. L., \& Wehmeyer, M. L. (2008). The Dynamic Relationship Between Context, Curriculum, and Student Learning: A Case for Inclusive Education as a Research-based Practice. Research \& Practice For Persons With Severe Disabilities, 33/34(4-1), 175-195.

Ješina, O., Kudláček, M., et al. (2011). Aplikovaná tělesná výchova. Olomouc: Univerzita Palackého v Olomouci.

Ješina, O., Bartoňová, R., Gebauer, S., Rybová, L., Kučera, M., \& Vyhlídal, T. (2011). Konzultant aplikovaných pohybových aktivit jako poradenský pracovník pro školní tělesnou výchovu. Česká kinantropologie, 15 (4), 95-106.

Jowsey, S. (1992). Can I play too? Physical education for physically disabled children in mainstreaming schools. London: David Fulton Publishers.

Kasser, S. L., \& Lytle, R. K. (2005). Inclusive Physical Activity: A Lifetime of Opportunities. Champaign, Ill.;: Human Kinetics.

Kudláček, M. (1997). Integrace osob na vozíku prostřednictvím pohybových aktivit. Diplomová práce. Olomouc: Univerzita Palackého.

Kudláček, M. (2008). Integrace žáků s tělesným postižením v kontextu školní tělesné výchovy. In M. Kudláček \& I. Machová (Eds.), Integrace - jiná cesta (pp. 11-19). Olomouc: Univerzita Palackého v Olomouci.

Lieberman, L. J., Houston-Wilson, C., \& Kozub, F. (2002) Perceived barriers to including students with visual impairments in general physical education. Adapted Physical Activity Quarterly, 19(3), 364-377.

Lienert, C., Sherrill, C., \& Myers, B. (2001). Physical educators' concerns about integrating children with disabilities: a cross-cultural comparison. Adapted Physical Activity Quarterly, 18(1), 1-17.

McMurray, C., A. (2003). The Use of Inclusive Opportunities to Promote Positive Attitudes towards Inclusion In Physical Activities. Unpublished Master's dissertation. Stellenbosch: University of Stellenbosch. 
Morley, D., Bailey, R., Tan, J., \& Cooke, B. (2005). Inclusive physical education: Teachers'views of including pupils with special education needs and/or disabilities in physical education. European Physical Education Review, 11(84), 84-107

Obrusníková, I. (1998). Varianty integrace v podmínkách školní tělesné výchovy. Diplomová práce. Olomouc: Univerzita Palackého.

Piéron, M., \& Cheffers, J. (1973). Research in sport pedagogy: Empirical analytical perspective. Schorndor: Verlag \& Hofman.

Sherrill, C. (1998). Adapted physical activity: Crossdisciplinary and lifespan. 5th ed. Boston, MA: WCB/Mc Graw-Hill.

Sherrill, C. (2004). Adapted physical activity: Crossdisciplinary and lifespan. 6 th ed. Dubuque, IA_Brown \& Benchman.

Smith, A. (2009). Disability and inclusion policy towards physical education and youth sport. Disability and youth sport. Abingdon, Oxon.

Spurná, M., Rybová, L., \& Kudláček, M. (2010). Participace žáků s tělesným postižením do školní tělesné výchovy. Aplikované pohybové aktivity $v$ teorii a praxi, 1 (1), 33-38.

Vágnerová, M. (2003). Psychický vývoj postiženého dítěte ve školním věku. In M. Vágnerová\& Z. Hadj Moussová, Psychologie handicapu. 4.část. Školní věk a dospívání postiženého dítěte (pp. 4-22). Liberec: Vysokoškolský podnik s.r.o.

Válková, H. (1974). Metoda hodnocení výkonu hráče košíkové v utkání. Praha: Český basketbalový svaz.basketbalový svaz. Válková, H. (2008). Integrace v evropském konceptu. In M.Kudláček \& T. Vyskočil (Eds.), Integrace - jiná cesta 2 (pp. 73-76). Olomouc: Univerzita Palackého v Olomouci.

Válková, H; Bartoňová, R. \& Ahmetašević A. 2012 Manuál pro hodnocení inkluzivních vyučovacích jednotek tělesné výchovy: DIC-CIT pro ATV. 1. vyd. Olomouc: Univerzita Palackého v Olomouci, $39 \mathrm{~s}$.

Winnick, J. P. (2000). Adapted physical education and sport. State University of New York, College at Brockport.

\section{Legislativní normy}

Ministerstva školství, mládeže a tělovýchovy. (1991). Zákon č. 564/1990 Sb., o státní správě a samosprávě ve školství.

Ministerstva školství, mládeže a tělovýchovy. (1991). Vyhláška č. 291/1991 Sb., o základní škole.

Ministerstvo školství, mládeže a tělovýchovy. (2002). Směrnice MŠMT k integraci dětí a žáků se speciálními vzdělávacími potřebami do škol a školských zařízení.

Ministerstvo školství, mládeže a tělovýchovy. (2005). Vyhláška č. 73/2005 Sb., o vzdělávání dětí a žáků se speciálními vzdělávacími potřebami a dětí a žáků mimořádně nadaných.

Ministerstvo školství, mládeže a tělovýchovy (2005). Vyhláška MŠMT č.72/2005 Sb., o poskytování poradenských služeb ve školách a školských poradenských zařízení. 